\title{
Institutional Determinants to Climate Variability Adaptation by Smallholder Irish Potato Farmers in Rubanda District, South Western Uganda
}

\author{
Frank Mugagga* ${ }^{\circledR}$, Julius Elepu, Alex Nimusiima, Yazidhi Bamutaze \\ Department of Geography, Geoinformatics and Climatic Sciences, Makerere University, Kampala, Uganda \\ Email: *mfrank@caes.mak.ac.ug
}

How to cite this paper: Mugagga, F., Elepu, J., Nimusiima, A. and Bamutaze, Y. (2019) Institutional Determinants to Climate Variability Adaptation by Smallholder Irish Potato Farmers in Rubanda District, South Western Uganda. American Journal of Climate Change, 8, 77-93.

https://doi.org/10.4236/ajcc.2019.81005

Received: December 4, 2018

Accepted: January 31, 2019

Published: February 3, 2019

Copyright $\odot 2019$ by author(s) and Scientific Research Publishing Inc. This work is licensed under the Creative Commons Attribution International License (CC BY 4.0).

http://creativecommons.org/licenses/by/4.0/

\begin{abstract}
Climate variability and change pose greater challenge not only to human life but to the environment at large. This study sought to evaluate the significance of institutional factors in climate variability adaptation of smallholder Irish potato farmers in Rubanda District, South Western Uganda with the objective of assessing the adaptation measures adopted by smallholder Irish potato farmers, determining the institutional factors that influence adoption of climate variability adaptation measures; and evaluating the institutional challenges that affect the adapting Irish potato farmers. A cross-sectional survey was undertaken to collect data from 197 systematically sampled smallholder farmers from two purposively selected sub counties (Muko and Bubaare) in Rubanda District, using structured questionnaires; whilst key informant interviews were used to elicit data from purposively selected personnel from the local government as well as private and civil society organizations. Multiple linear regression was used to determine the relative influence of selected variables on adaptation measures against climate variability. Results indicate that smallholder Irish potato farmers are adapting to climate variability through agronomic measures such as terracing, mulching, contour ploughing, changing planting dates, early planting, crop-rotation, and technology related measures such as rain water harvesting technologies, adaptive varieties and fertilizers among others. Results from multiple linear regression analysis show that several institutional factors are influencing adoption of climate variability adaptive measures with the most significant ones being access to agricultural extension services, cultivated area and size of land owned. Despite the interventions undertaken, adaptation to climate variability is constrained by the limited access to financial/credit resources and in-
\end{abstract}


adequate technical capacity as well as limited access to information and irregularity of extension services. The study recommends that public and private institutions and personnel, both technical and political, at the various levels of local government, work together to improve extension services, communication as well as enhancing access to credit facilities among smallholder farmers, who will also need to further strengthen existing social groups to enhance their bargaining power.

\section{Keywords}

Adaptation, Climate Variability, Institutional Factors, Smallholder Farmers, South Western Uganda

\section{Introduction}

Climate variability poses a threat to the agricultural sector and food security which indirectly hampers the attainment of Sustainable Development Goals [1] [2] [3]. Climate variability induced events such as floods, droughts, unreliable rainfall and heat waves have increased and are having severe impacts on both natural and human systems across the globe [4] [5] [6]. The need for adaptation is therefore higher because these events are expected to be adverse especially for developing countries such as those in Africa due to their inherent poor infrastructure and heavy reliance on climate sensitive economic sectors such as rain-fed agriculture [4] [7] [8] [9].

Agriculture, the main economic activity in most developing countries, represents one of the most fragile economic sectors to climate variability [1]. In Uganda, for example, agriculture provides employment to $73 \%$ of the total population and is a major livelihood of about $90 \%$ of the rural households [5] [10]. In addition, it contributes $23.5 \%$ to GDP [11]. Despite the sector's contribution to the economy of Uganda, most of the agriculture is rain-fed hence making it sensitive to climate induced events such as droughts and floods [6] [12].

Several studies on climate variability and change [4] [8] [13] [14] [15] suggest that temperatures in Uganda will increase by $1.5^{\circ} \mathrm{C}$ in the next 20 years and up to $4.3^{\circ} \mathrm{C}$ by 2080 ; whilst rainfall is expected to increase in some areas and decrease in other areas with a national average ranging from $-7 \%$ to $14 \%$ relative to the 1970-1999 average by 2030 [16]. These changes will be significant for agriculture and food security [3] [8]. The south western highlands have not been spared by this phenomenon as studies report that the area is experiencing changes in precipitation and temperature [12] [17]. For instance, smallholder farmers are already experiencing the negative effects of climate variability such as decline in crop yields, declining soil fertility because of accelerated soil erosion and proliferation of pests and diseases [5] [18] [19].

Uganda is one of the major producers of Irish potato which is mainly grown 
in highland areas (1500 - $3000 \mathrm{~m} \cdot$ asl) such as Kigezi highlands (in the Districts of Kabale, Rubanda and Kisoro), slopes of Mt. Elgon (Mbale and Kapchorwa) as well as Nebbi District where rainfall is abundant and temperatures are optimal for the growth of tubers [13] [20] [21]. Irish potatoes are both a staple food and a major source of income for most of the households in the Kigezi Highlands [20] [22].

Due to the susceptibility of Irish potato to climate variability and its immense contribution to the economy of south western Uganda, it becomes apparent to minimize these impacts, through adaptation [4] [23].

Some studies such as [7] [24] [25] [26] reported that adaptation to climate variability at local level is influenced by several factors including access to financial and information resources, managerial ability, networks of social and institutional arrangement among. Other studies such as [27] have focussed on policy implementation constraints and gaps without considering that how adaptation pathways are determined by institutional related factors.

In order to bridge this knowledge gap, we set out to evaluate the significance of institutional factors on adaptation by smallholder Irish potato farmers to climate variability in Rubanda District since it is the highest producer of Irish potato in Kigezi highlands. Specifically, three objectives informed the study viz; 1) To assess the adaptation measures adopted by smallholder Irish potato farmers; 2) To determine the institutional factors that influence adoption of climate variability adaptation measures; and 3) To evaluate the institutional challenges that affect the adapting Irish potato farmers.

\section{Materials and Methods}

\subsection{Location of the Study Area}

The study was conducted in Muko and Bubaare sub-counties in Rubanda District located in the South West of the Republic of Uganda (Figure 1). Rubanda District is comprised of seven (7) sub-counties and two town councils, namely Bubaare, Bufundi, Hamurwa, Ikumba, Ruhija, Nyamweru and Muko; Rubanda and Humurwa Town Council. It lies at an approximate altitude ranging between $1219 \mathrm{~m}-2347 \mathrm{~m}$ above sea level [28]. The population of the District was 196,896 people based on the 2014 Population Census [10].

Rubanda has a montane climate with a bimodal rainfall pattern with the first rain season from March to May and the second rainfall season from September to November with two dry periods of June to August and December to February. It has a mean annual rainfall of $1480 \mathrm{~mm}$ and a mean annual mean temperature of $17.2^{\circ} \mathrm{C}$ [28].

The soils are generally volcanic although some parts are comprised of ferralisols and andosols [18].

\subsection{Sampling Procedure and Data Collection}

Rubanda District was purposively selected because it is the highest producer of 


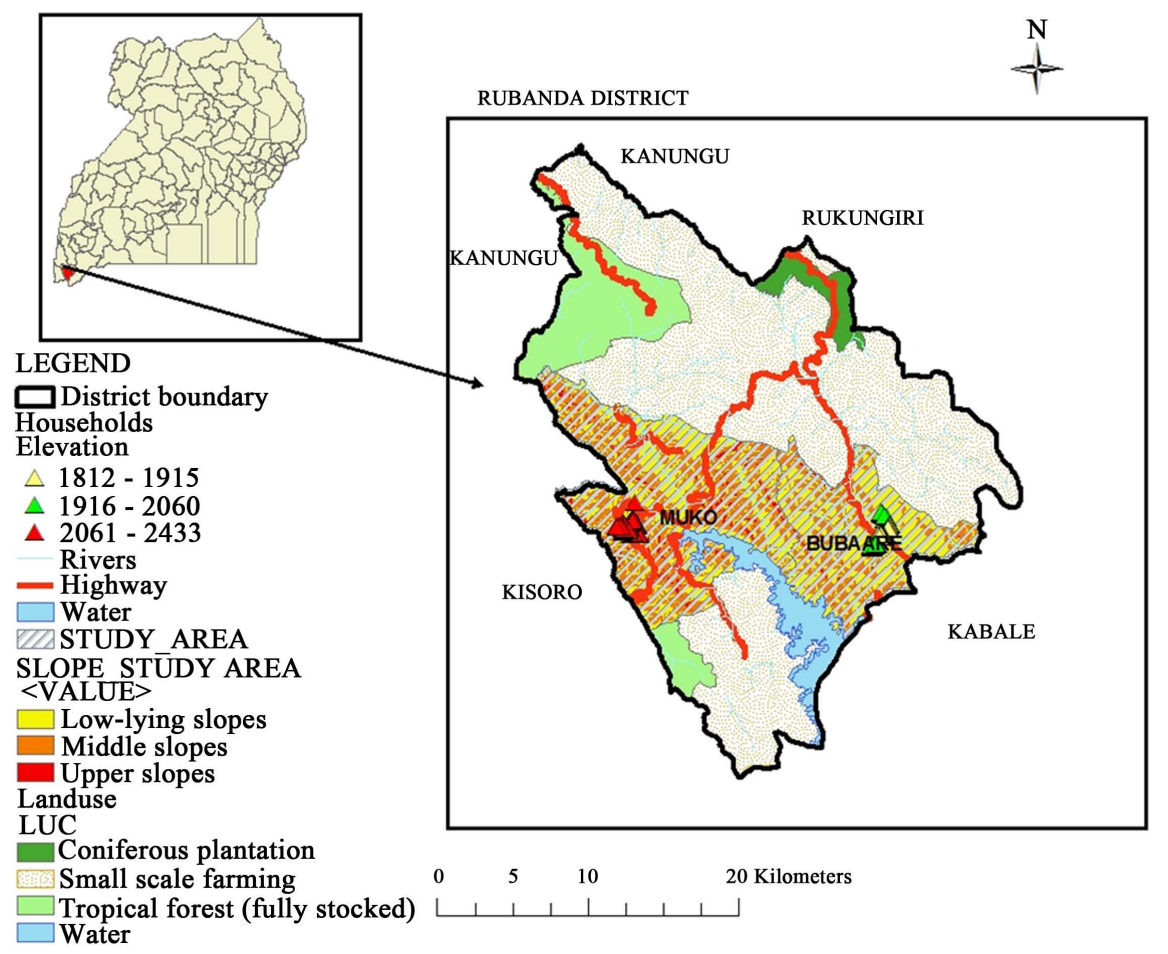

Figure 1. Map showing the location of the study area.

Irish potato in Kigezi region. Two sub counties (Muko and Bubaare) were purposively selected because of their unique characteristics, in that, they are located at relatively different altitudes, are highly populated and are home to several agricultural research institutes. A multistage sampling procedure was employed to select the respondents. Two parishes were randomly selected from each subcounty. After selecting the parishes, 4 villages were randomly selected from each parish making a total of 8 villages (see Table 1). A total of six (6) key Informants were purposively selected from the District Technical Staff and NGOs based on the key themes of the study. The key informants included Local Council Leader (LC), Regional Farm Manager at the International Fertilizer Development Center (IFDC), the Manager at Nature Uganda, Principal Technician at Kachwekano Zonal Agricultural Research and Development Institute (KAZARDI), District Natural Resource Officer (DNRO), and the District Production and Commercial Officer (DPO).

The sample size was obtained using a formula by Yamane (1967)

$$
n=\frac{N}{1+N\left(e^{2}\right)}
$$

where $n=$ sample size, $N=$ total number of households involved in subsistence farming, $e=$ margin of error.

By using the equation above with a confidence level of $90 \%$ and marginal error of $10 \%$, a computation from a population of 9285 and 6486 subsistence farm households (UBOS, 2014) for Muko and Bubaare yielded 99 and 98 farmers as sample size respectively. The margin of error was raised to $10 \%$ to downscale the 
Table 1. Sample selection of respondents.

\begin{tabular}{cccc}
\hline Subcounty & Parish & Selected Villages & Sample size \\
\hline \multirow{2}{*}{ Muko } & Karengyere & Nyamiyaga A & 25 \\
& & Rushekye & 24 \\
& Butare & Igabiro & 26 \\
& Nyamiyaga & Mubyeza & 24 \\
Bubaare & & Kabindi & 25 \\
& & Hamurara & 24 \\
Tubaare & Bubaare TC & 25 \\
& 4 & Kitumbezi & 24 \\
\hline
\end{tabular}

sample size owing to the financial limitations and the time needed to finish the study. The categories of respondents included smallholder farmers and the Key Informants.

Primary data collection entailed Key Informant Interviews (KII), field observations and questionnaires administered on 197 respondents that were systematically and randomly selected from a pool of smallholder subsistence Irish potato farmers (Figure 1). The questionnaire was pretested in Bubaare sub-county before administering it in the field.

\subsection{Data Analysis}

The collected data was verified, coded and entered into a Statistical Package for Social Scientists software (SPSS version 23). Descriptive statistics such as frequencies, mode and percentages were generated to determine the socio-economic and demographic characteristics of the respondents, adaptation measures employed by farmers and institutional challenges to adaptation. Whilst a Multiple linear regression was run to determine the institutional factors that influence adoption of adaptation measures.

The linear regression model was specified as follows

$$
Y_{i}=\beta_{0}+\beta_{1} X_{1}+\beta_{2} X_{2}+\beta_{3} X_{3}+\beta_{4} X_{4}+\beta_{5} X_{5}+e
$$

where,

$Y_{i}=$ number of adaptation measures adopted by farmer $i, \beta_{0}$-intercept, $\beta_{1}-$ $\beta_{5}=$ coefficients to be estimated, $X_{1}$-access to information measured by a proxy indicator, distance to the nearest extension service provider, $X$-access to credit, $X_{3}$ - group membership, $X_{4}$-cultivated area for Irish potato, $X_{5}$-size of land owned and $e$-error terms.

Narratives from Key Informants were also used to emphasise the voices of the respondents. 


\section{Results and Discussion}

\subsection{Socio-Economic and Demographic Characteristics of the Respondents}

This section presents key characteristics of the respondents that were involved in the study.

Over half of the respondents $(58.9 \%)$ were males while females constituted $41.1 \%$. Majority of the households (79.7\%) were male-headed, aged between 47 $62(32.3 \%)$. Furthermore, most of the respondents were primary levers $(67 \%)$, while $20.3 \%$ had attained secondary education, $2.5 \%$ had attained university education and $10.2 \%$ had not attained any level of education, majority of whom were females.

In terms of access to credit, results in Table 2 indicate that $56.48 \%$ did not have access to credit facilities while $43.52 \%$ reported that they had access to credit facilities. The number of those who borrowed money from the bank was minimal $(16.2 \%)$. Over ninety percent $(90.2 \%)$ of the respondents belonged to a group, of whom only $20 \%$ had ever accessed extension services about climate change adaptation.

\subsection{Adaptation Measures Adopted by Smallholder Potato Farmers}

Adaptation measures were categorized as technological, agronomical or any other form that is not captured in the two categories. The findings in terms of the categories are presented in Table 3.

\subsubsection{Technological Measures}

The most common adaptation measures adopted by smallholder farmers included application of fertilizers, planting adaptive crop varieties, irrigation agriculture, spraying and water harvesting technologies. The high use of fertilizers is partly because the soils are exhausted and the sensitization received by farmers from NGOs and government extension workers. For example, the International Fertilizer Development Center (IFDC) trains farmers on the use of fertilizers in crop production. The use of fertilizers helps in replenishing lost soil nutrients and increasing nutrient availability in the soil which increases crop productivity and resistance to pests and diseases [29].

Planting fast maturing and drought resistant varieties is suitable in areas with land shortage such as Rubanda where the study was conducted. This is consistent with the findings by [17] who reported the use of improved varieties as the main adaptation measure among the agricultural households in Ghana and South Western Uganda respectively.

Finally, [30] observed that farmers in Bufundi catchment in Rubanda District were responding to climate variability through rain water harvesting. Moreover [31] highlights it as the most common measure in Uganda and among those that should be promoted due to their associated positive impacts. 
Table 2. Socio-economic and demographic characteristics.

\begin{tabular}{|c|c|c|}
\hline Characteristic/Variable & Frequency & Percent \\
\hline \multicolumn{3}{|l|}{ Sex of the respondent } \\
\hline Male & 116 & 58.9 \\
\hline Female & 81 & 41.1 \\
\hline \multicolumn{3}{|l|}{ Age of the respondent } \\
\hline $15-30$ & 47 & 24.1 \\
\hline $31-46$ & 59 & 30.3 \\
\hline $47-62$ & 63 & 32.3 \\
\hline $63-78$ & 24 & 12.3 \\
\hline$>78$ & 2 & 1.0 \\
\hline \multicolumn{3}{|l|}{ Level of education } \\
\hline Primary & 132 & 67.0 \\
\hline Secondary & 40 & 20.3 \\
\hline University/tertiary & 5 & 2.5 \\
\hline None & 20 & 10.2 \\
\hline \multicolumn{3}{|l|}{ Access to credit } \\
\hline Yes & 84 & 43.5 \\
\hline No & 109 & 46.5 \\
\hline \multicolumn{3}{|l|}{ Extension services } \\
\hline Yes & 39 & 29.0 \\
\hline No & 156 & 80.0 \\
\hline \multicolumn{3}{|l|}{ Group membership } \\
\hline Yes & 175 & 90.2 \\
\hline No & 19 & 9.8 \\
\hline $\mathrm{N}=197$ & & \\
\hline
\end{tabular}

Table 3. Adaptation measures adopted by smallholder Irish potato farmers in Rubanda District.

\begin{tabular}{|c|c|c|c|}
\hline \multicolumn{2}{|c|}{ Adaptation measures types } & \multirow{2}{*}{$\begin{array}{c}\text { Frequency }^{*} \\
159\end{array}$} & \multirow{2}{*}{$\begin{array}{c}\text { Percent \% } \\
80.7\end{array}$} \\
\hline \multirow{5}{*}{ Technological } & Application of fertilizers & & \\
\hline & Planting fast maturing varieties & 103 & 52.3 \\
\hline & Planting drought tolerant varieties & 58 & 29.4 \\
\hline & Drip irrigation agriculture & 17 & 8.6 \\
\hline & Water harvesting technologies & 91 & 46.2 \\
\hline \multirow{6}{*}{ Agronomic Measures } & Early planting & 183 & 92.9 \\
\hline & Mulching & 33 & 16.8 \\
\hline & Terracing & 180 & 91.4 \\
\hline & Contour ploughing & 147 & 74.6 \\
\hline & Fallowing & 12 & 6.1 \\
\hline & Shifting cultivation & 8 & 4.1 \\
\hline \multirow{5}{*}{ Other measures } & Migration & 8 & 4.1 \\
\hline & Changing planting dates & 171 & 86.8 \\
\hline & Borrowing & 79 & 40.1 \\
\hline & Stagger planting & 28 & 14.2 \\
\hline & Off farm activities & 96 & 48.7 \\
\hline
\end{tabular}

${ }^{\star}$ The frequencies are a result of multiple responses. 


\subsubsection{Agronomic Measures}

The most popular agronomic adaptive measures included early planting, mulching, terracing, contour ploughing, fallowing, shifting cultivation, timely weeding, use of compost manure, intercropping and crop rotation. The use of soil and water conservation measures such as terracing and contour ploughing is significant in improving the water holding capacity of the soil and offsetting runoff [17]. The findings also confirm the observations made by other studies that contour ploughing and terracing are among the adaptation measures within the agricultural communities [31] [32]. The findings are also consistent with the study by [33] that observed timely planting as the most common measure adopted by Irish Potato farmers in Nyandarua County in Kenya.

Meanwhile, a small number of respondents adopted shifting cultivation and fallowing. The low adoption of shifting cultivation and fallowing can be explained by the land shortage in the area as a result of increasing population [28]. Moreover, [31] categorizes shifting cultivation among measures that are not sustainable, given the needs and pressure of limited land.

Mulching has been envisaged as a simple climate variability adaptation measure that improves soil fertility, infiltration capacity of the soil, reduces evaporation and erosion [34]. This practice was not common among the Irish potato farmers. The findings in the study are consistent with the observations made by [17] that mulching was not common among the Irish Potato farmers in Kigezi highlands because the practice does not favor the crop due to limited space between the potato plants for the mulch. On the contrary though, [32] pointed out that mulching was among the highest climate variability measure used among the agricultural communities in Rwenzori region. Thus, climate variability adaptation measures are context specific and should not be generalized across agricultural communities. Care should be taken on the type of crop grown in a geographical location.

\subsubsection{Other Adaptive Measures}

The most common ones included migration, changing planting calendar, borrowing, staggered planting and off-farm employment. Adaptation measures such as intercropping, crop rotation, use of compost manure and timely weeding are not unique to Rubanda District. Scholars such as [31] [32] [35] postulate that croprotation maintains soil fertility and avoids the build-up of soil-borne diseases.

Irish potato farmers are also changing planting dates due to the unpredictable and erratic rainfall seasons in the area. The results are consistent with [36] who posited that if the agricultural production problem is meteorologically mediated, farmers can adapt agricultural production to climatic conditions by cautiously choosing the date of sowing or planting. Changes in planting calendar are also identified as one of the priority crop husbandry practices that farmers have adopted to respond to the erratic rainfall seasons in Uganda [30]. Similar findings have observed changing the planting calendar as one of the adaptive meas- 
ures among the agricultural communities in mountain areas such as Manafwa in Eastern Uganda and Kasese in mountain Rwenzori region respectively [5] [34].

Lastly, migration was the least adopted measure possibly because of its negative environmental impacts such as migration into wetlands, overcrowding and psychological disorders. Migrating to urban areas causes social and economic scrambles which can result to family disintegration and instability [30]. Where a majority of the able bodied migrate, it strips off the farm family left behind of labor required for production hence leaving them more vulnerable to famine per se.

\subsection{Institutional Determinants Influencing the Adoption of Adaptation Measures}

Generally, the institutional factors considered to influence the adoption of adaptive measures include social networks (group membership), size of land, access to information through extension, access to credit and land size. A multiple linear regression was run to establish the most significant factors influencing farmers' adaptation. A combination of independent variables significantly predicted the number of adaptation measures adopted, $\mathrm{F}(5,143)=9.805, \mathrm{P}<0.001$, with three variables significantly contributing to the prediction. The beta weights, presented in Table 4, suggest that area of land cultivated for Irish potatoes contributes most to predicting the adaptation measures adopted, and that having access to information and the size of land owned also contribute to this prediction. The details are presented in Table 4.

\subsubsection{Social Networks}

Membership support groups influences the adoption of adaptive measures. Those who belonged to a social group adopted more measures compared to those with no membership. The social groups found included: self-help groups, welfare groups, cooperative societies, farmer groups and a climate change group.

Table 4. A multiple linear regression analysis for institutional factors influencing the adoption of adaptation measures.

\begin{tabular}{|c|c|c|c|c|c|}
\hline \multirow[t]{2}{*}{ Independent variables } & \multicolumn{2}{|c|}{$\begin{array}{l}\text { Unstandardized } \\
\text { Coefficients }\end{array}$} & \multirow{2}{*}{$\begin{array}{c}\text { Standardized } \\
\text { Coefficients } \\
\text { Beta }\end{array}$} & \multirow[t]{2}{*}{$\mathrm{t}$} & \multirow[t]{2}{*}{ Sig. } \\
\hline & $\mathrm{B}$ & Std. Error & & & \\
\hline (Constant) & 9.811 & 0.958 & & $10.241^{\star * \star}$ & 0.000 \\
\hline $\begin{array}{l}\text { Distance of the nearest } \\
\text { extension service provider }\end{array}$ & -0.112 & 0.033 & -0.324 & $-3.354^{\star \star}$ & 0.001 \\
\hline Access to credit & 0.617 & 0.393 & 0.150 & 1.569 & 0.119 \\
\hline Group membership & 0.093 & 0.498 & 0.014 & 0.186 & 0.852 \\
\hline Acreage under cultivation for Irish & 1.628 & 0.404 & 0.422 & $4.025^{\star * *}$ & 0.000 \\
\hline Size of land owned & -1.055 & 0.312 & -0.366 & $-3.379^{\star *}$ & 0.001 \\
\hline
\end{tabular}

Note: Adjusted $\mathrm{R}^{2}=0.255, \mathrm{~F}(5,143)=9.805, \mathrm{P}<0.001 ;{ }^{* * *}$, ${ }^{* *}$ significant at $\mathrm{P}<0.001$ and $\mathrm{P}<0.01$ respectively. 
The most dominant group types were self-help groups (62.7\%), followed by welfare groups with $27.1 \%$ of the respondents; whereas farmers groups, climate change groups and cooperative societies had $9 \%, 0.6 \%$ and $0.6 \%$ respectively. Social networks, especially self-help groups and welfare groups were dominant in the area because the friends in need system are a form of informal micro insurance strategy for the low-income households and a tool for reducing vulnerability of the poor to risks. The social groups act as sources of credit, information on farming and support during hard times. Studies such as [7] [36] [37] have reported that social groups serve as informal insurance schemes, sensitization hubs and establishment of adaptation measures and help to improve resilience to climate variability.

\subsubsection{Access to Information}

There was a significant negative association between the number of adaptations measures adopted by smallholder farmers and access to information (measured by distance to the nearest extension service provider as a proxy indicator). The results suggest that an increase in the distance to extension service provider would decrease the number of measures adopted by 0.112 . The significance of the variable points to the relevance of access to information about climate variability adaptation. For example, [38] found that farmers who were aware of climate change were more likely to migrate to areas less prone to drought in north-east Ghana. Access to information through extension is presumed to enhance farmers' knowledge hence promoting adaptation. For example, [39] noted that extension facilitates the acquisition of knowledge and thus, enhances the adoption of improved technology. Similar observations are shared by a number of studies in African countries such as Kenya, Tanzania and Ghana [38] [40] [41] which reported a strong relationship between access to information and adaptation behavior of farming households.

\subsubsection{Access to Credit}

A one standard deviation positive change in access to credit holding all other predictor variables constant, will increase adoption of adaptation measures by 0.617 standard deviations. This makes sense since access to credit eases financial constraints for funding adaptation processes including purchasing improved seeds among others. This is in line with other studies that reported that access to credit influenced and increased the likelihood of adoption of adaptation measures [5] [7] [41] [42].

\subsubsection{Cultivated Area}

There was a significant positive association between the number of adaptation measures adopted by smallholder farmers and the size of cultivated land for Irish potatoes $(\mathrm{P}<0.001)$. A unit increase in the cultivated area under Irish potatoes, would increase adoption of adaptation measures by 1.628 standard deviations. It can be inferred that farmers with more cultivated land have more capital and resources required for adaptation. For example, [42] revealed that increase in 
cultivated area increases the probability of adopting adaptation measures such as improved varieties and irrigation which requires large investment costs.

\subsubsection{Size of Land Owned}

The size of land owned by a farmer is negatively and significantly related to the number of adaptation measures adopted $(\mathrm{P}<0.01)$. For a one standard deviation negative change in the size of land owned, the results reveal a decrease in adoption of adaptation measures by 1.055 standard deviations. This could be because farmers with much land have less fear of being affected by climate variability vagaries compared to their counterparts. Farmers with much land are likely also to have many farm plots with different plot characteristics such soil fertility and topography which are affected differently by climate variability impacts. This could have explained their reluctance use fertilizers, improved varieties and mulching for example because the risks are spread. The same notion was reported by [43] in Ethiopia who found a negative relationship between land size and adoption of adaptation measures. They therefore argued that plot level characteristics determined the level of adaptation than size of land owned by a farmer. A study done by [33] in Kenya reported similar findings.

\subsubsection{Support from the NGOs and International Organizations towards Adaptation to Climate Variability}

Discussions with Key informants reveal that there are several organizations that operate in the area that are aiding farmers to respond to climate vagaries. Notable among them is IFDC (International Fertilizer Development Center), Nature Uganda, Africa 2000 Network and Kachwekano-Zonal Agricultural Research and Development Institute (ZARDI). Nature Uganda for example, is promoting sustainable land management and sustainable use of environmental resources. Kachwekano ZARDI supports farmers through multiplication of improved potato cultivars, farmer trainings and group formation. Additionally, IFDC trains farmers on fertility management by use of fertilizers and it has also piloted small-scale irrigation schemes (drip irrigation) in some parts of the District. The support rendered by these agencies has helped improve the adaptation levels in the study area.

\subsection{Institutional Challenges to Climate Variability Adaptation}

This section presents a summary of findings on the institutional challenges impeding adaptation to climate variability among smallholder farmers. These factors make it harder for smallholder farmers to execute climate variability adaptation measures (Table 5).

\subsubsection{Inadequate Funding}

Results indicate that the most resounding institutional challenge is inadequate funding and budgetary allocation (72.3\%). The technical staff at the District also reiterated inadequate funding for climate variability related adaptation activities. Notably, in the financial year 2016/2017, the Natural Resource and Production 
Table 5. Institutional challenges hampering adaptation by smallholder farmers.

\begin{tabular}{ccc}
\hline Challenges & Frequency & Percent (\%) \\
\hline Insecure land tenure & 80 & 41.0 \\
Lack of plan and policy guidelines & 128 & 65.6 \\
Gender discrimination & 60 & 30.8 \\
Inadequate funding and budgetary allocation & 142 & 72.3 \\
Inadequate information & 127 & 65.1 \\
Inadequate human resource on climate adaptation & 119 & 61.0 \\
Limited access to credit & 104 & 53.3 \\
\hline
\end{tabular}

Note: $\mathrm{N}=197$; the results present a summary from multiple responses.

and Marketing departments that are directly mandated to handle natural resource management and agriculture issues, were allocated $0.02 \%$ and $0.37 \%$ of the Total budget [44]. This is in tandem with [16] who reported that inadequate funding and budgetary allocation to the concerned departments was a big challenge to climate variability and change adaptation in Uganda which clearly agrees with the study findings.

\subsubsection{Inadequate Technical Capacity}

In terms of personnel, there is inadequacy of qualified human resource especially in the field of climate science to deal with climate variability adaptation as was reported by the Key Informants at the District and NARO (National Agricultural Research Organization) regional office in Rubanda District. The key sectors such as Natural Resource Management and the Production staffing level is not adequate creating policy implementation challenges. This is reflected in the District Development Plan 2015/2016-2019/2020 [45]. Table 6 reflects the discrepancies in staffing levels at Kabale District whose staff still ran Rubanda District as well at the time of data collection. This impedes adaptation process since farmers do not get timely and viable information to counter climate variability associated impacts. A study conducted in Rakai District observed limited technical capacity as the major institutional challenges to adaptation [27]. Another related study [23] reported similar findings.

\subsubsection{Inadequate Access to Scientific and Technical Information}

Relatedly, inadequate access to information through extension services is reportedly hampering adaptation initiatives. A small percentage (20\%) of the respondents reported to have received extension services about climate variability adaptation. Majority (80\%) did not have access to extension services (Table 2). The result also reveals that although smallholder farmers (57.1\%) air their views to extension providers, the implementation bit is lacking as $65.2 \%$ reported that their views are never considered. The findings resonate with [27] who found inadequate access to extension services as a limiting factor for adaptation in Rakai district in Uganda. 
Table 6. District staffing levels.

\begin{tabular}{ccccc}
\hline No. & Department & Approved position & Filled position & $\%$ age \\
\hline 1 & Administration & 24 & 14 & 58.33 \\
2 & Production and Marketing & 15 & 2 & 13.33 \\
3 & Statutory Bodies & 12 & 8 & 66.67 \\
4 & Finance & 19 & 16 & 68.42 \\
5 & Planning & 8 & 4 & 50.00 \\
6 & Works \& Technical Services & 25 & 20 & 80.00 \\
7 & Education and Sports & 14 & 9 & 64.29 \\
8 & Community Development & 9 & 6 & 66.67 \\
9 & Natural Resources & 19 & 13 & 68.42 \\
10 & Internal Audit & 6 & 2 & 33.33 \\
11 & Health & 12 & 10 & 83.33 \\
12 & Sub-counties & 296 & 148 & 50.00 \\
13 & Lower Health units & 288 & 175 & 60.76 \\
\hline
\end{tabular}

Source: Human Resource Department, Kabale District, 2017.

\subsubsection{Lack of Plans and Policy Guidelines}

This was reported to be among the constraints to adaptation to climate variability in the study area. Discussions with key informants revealed that there are no clear policies, ordinances and plans to guide adaptation.

"There are genetically modified potato varieties that are in place but they cannot be officially released because of lack an enabling biotechnology law," Principal Technician, Kachwekano ZARDI. Additionally, technical staff at the District also cited that implementation of the existing laws faces frustration from the political wing. The findings agree with the findings by [27] who reported political interference, lack of by-laws and absence of action plans to be among the key institutional challenges to adaptation in Uganda.

\subsubsection{Limited Access to Credit Facilities}

Institutional support through credit facilities is inadequate. Results in Table 2 indicate that over half (56.48\%) of the respondents did not have access to credit facilities. The number of those who borrowed money from the banks were minimal (16.2\%). This could be explained by the fact that only $15.7 \%$ of the respondents owned a bank account. Majority of the respondents' source of credit was from the saving groups (35.9\%) and relatives (26.5\%) indicating limited access to formal credit institutions due to lack of collateral. The lack of access to credit facilities was also reported as a challenge to small-scale farmers' adaptation in Zimbabwe [25].

\section{Conclusions and Policy Implications}

Adaptation literature highlights developing countries to be highly predisposed to 
climate variability associated events due to their reliance on rain-fed agriculture. Agriculture is the major source of livelihood in most parts of Africa including Uganda; and if jeopardised puts rural farmers at a risk hence making adaptation not only necessary but inevitable. Different adaptation measures have been employed by smallholder farmers in response to climate variability. We infer that the adoption of these adaptation measures has the potential to increase adaptive capacity of the smallholder Irish potato farmers and reduce sensitivity to climate variability stressors.

The paper has showed that access to information via extension services, access to credit, social networks, size of land and cultivated area determine farmer's ability to adapt to climate variability. The study finds access to information as a crucial determinant of the adoption of adaptation measures. This calls for policies aiming at promoting adaptation to climate variability to emphasise the role of extension services to the farmers. These services should include training programmes on cultivation techniques, pests and disease management and adoption of irrigation farming.

The results also highlight the role played by social capital in fostering adaptation to climate variability. Policy interventions geared towards enhancing informal social networks can promote the development and adoption of adaptation measures since they increase information flow.

Despite the adaptive measures taken to counter climate variability, farmers are confronted by several challenges that are slowing their adaptation process. These include institutional issues like inadequate funding and financing of climate adaptation activities, inadequate human resource, limited access to information on climate variability, poor implementation of environmental policies and limited access to credit facilities as a result of lack of collateral impede adaptation efforts by smallholder farmers.

We thus conclude that to thwart these challenges, there is need to develop clear channels of communication to facilitate smallholder farmers' access to climate information as well as equipping the District with adequate technical staff in the field of climate science while increasing funding and budget allocation towards climate variability adaptation.

\section{Acknowledgements}

The study was funded by the Makerere-Sida Capacity Building Programme 2015-2020 under the partnership for Building Resilient Ecosystems and Livelihoods to Climate Change and Disaster Risks (BREAD) project.

\section{Conflicts of Interest}

The authors declare no conflicts of interest regarding the publication of this paper.

\section{References}

[1] Bannayan, M., Paymard, P. and Ashraf, B. (2016) Vulnerability of Maize Production 
under Future Climate Change: Possible Adaptation Strategies. Journal of the Science of Food and Agriculture, 96, 4465-4474. https://doi.org/10.1002/jsfa.7659

[2] Denton, F., Wilbanks, T., Abeysinghe, A.C., Burton, I., Gao, Q., Lemos, M.C., et al. (2014). Climate-Resilient Pathways: Adaptation, Mitigation, and Sustainable Development. In: Field, C.B., Barros, V.R., Dokken, D.J., Mach, K.J., Mastrandrea, M.D., Bilir, T.E., et al., Eds., Climate Change 2014: Impacts, Adaptation, and Vulnerability. Part A: Global and Sectoral Aspects. Contribution of Working Group II to the Fifth Assessment Report of the Intergovernmental Panel on Climate Change, Cambridge University Press, United Kingdom and New York, NY, USA, 1101-1131.

[3] Lwasa, S., Mugagga, F., Wahab, B., Simon, D., Connors, J. and Griffith, C. (2013) Urban Climate Urban and Peri-Urban Agriculture and Forestry: Transcending Poverty Alleviation to Climate Change Mitigation and Adaptation. Urban Climate, 7, 92-106. https://doi.org/10.1016/j.uclim.2013.10.007

[4] IPCC (2014) Synthesis Report; Fifth Assessment Report to the IPCC. Geneva, Switzerland.

[5] Mugagga, F. (2017) Perceptions and Response Actions of Smallholder Coffee Farmers to Climate Variability in Montane Ecosystems. Environment and Ecology Research, 5, 357-366. https://doi.org/10.13189/eer.2017.050505

[6] Nimusiima, A., Basalirwa, C.P.K. and Majaliwa, J.G.M. (2013) Nature and Dynamics of Climate Variability in the Uganda Cattle Corridor. African Journal of Environmental Science and Technology, 7, 770-782. https://doi.org/10.5897/AJEST2013.1435

[7] Amare, A. and Simane, B. (2017) Determinants of Smallholder Farmers' Decision to Adopt Adaptation Options to Climate Change and Variability in the Muger Sub Basin of the Upper Blue Nile Basin of Ethiopia. Agriculture \& Food Security, 6, 64. https://doi.org/10.1186/s40066-017-0144-2

[8] Hepworth, N. and Goulden, M. (2008) Climate Change in Uganda: Understanding the Implications and Appraising the Response. Edinburg.

[9] Pulwarty, N.R., Duc, D.M., Elshinnawy, I., Redsteer, M.H., Huang, H.Q., Nkem, J.N. and Rodriguez, R.A.S. (2014) Adaptation Planning and Implementation: In: Barros, K., Dokken, V.R., Mach, D.J., Mastrandrea, K.J., Bilir, M.D., Chatterjee, T.E. and Ebi, M., Eds., Climate Change 2014: Impacts, Adaptation, and Vulnerability. Part A: Global and Sectoral Aspects. Contributions of Working Group II to the Fifth Assessment Report of the Intergovernmental Panel on climate Change, Cambridge, United Kingdom and New York City, USA, 869-898.

[10] UBOS (2014) The National Population and Housing Cencus 2014. Kampala, Uganda.

[11] UBOS (2017) Uganda Bureau of Statistics 2017 Statistical Abstract. Kampala, Uganda.

[12] Kikoyo, D.A. and Nobert, J. (2015) Assessment of Impact of Climate Change and Adaptation Strategies on Maize Production in Uganda. Physics and Chemistry of the Earth, 93, 37-45. https://doi.org/10.1016/j.pce.2015.09.005

[13] Baastel (2014) Economic Assessment of the Impacts of Climate Change in Uganda: Regional Scale Climate Change Projections of the Annual, Seasonal and Monthly near Surface Temperatures and Rainfall in Uganda. United States Agency for International Development, Tetra Tech ARD.

[14] 2008 LTS Scoping Study [Steynor, A., Jack, C. and Smith, C.] DFID Resource Centre for Environment, Water and Sanitation, 1.

[15] USAID (2013) Uganda Climate Change Vulnerability Assessment Report. Arling- 
ton, Tetra Tech ARD.

[16] Hepworth, N. (2010) Climate Change Vulnerability and Adaptation Preparedness in Uganda.

[17] Twagiramaria, F. and Tolo, C.U. (2016) Climate Variability and Soil Nutrients Status along Altitudinal Gradient in Kigezi Highlands, Southwestern Uganda. Natural Resources, 7, 1-22.

[18] Bagoora, F.K. (2010) Challenges of Climate Change in Mounatin Ecosystems in Africa Kampala. In: United Nations Climate Change Conference COP16 and CMP6, National Environment Management Authority, Cancun, 29.

[19] Hisali, E., Birungi, P. and Buyinza, F. (2011) Adaptation to Climate Change in Uganda: Evidence from Micro Level Data. Environmental Change, 21, 1245-1261. https://doi.org/10.1016/j.gloenvcha.2011.07.005

[20] Ferris, R.S., Okoboi, G., Crissmann, C., Ewell, P. and Lamega, B. (2002) Performance and Growth of Irish Potatoes as a Component for Development of Strategic Exports in Uganda. Association for Strengthening Agricultural and Research in Eastern and Central Africa, Kampala.

[21] Kaguongo, W., Gildemacher, P., Demo, P., Wagoire, W., Kinyae, P., Andrade, J. and Fuglie, K. (2008) Farmer Practices and Adoption of Improved Poatao Varieties in Kenya and Uganda (5 No. 2008) Lima, Peru.

[22] Mbowa, S. and Mwesigye, F. (2016) Investment Opportunities and Challenges in the Irish Potato Value Chain in Uganda.

[23] Moser, S.C. and Ekstrom, J.A. (2010) A Framework to Diagnose Barriers to Climate Change Adaptation. PNAS, 107, 22026-22031.

https://doi.org/10.1073/pnas.1007887107

[24] Taruvinga, A., Visser, M. and Zhou, L. (2016) Determinants of Rural Farmers' Adoption of Climate Change Adaptation Strategies: Evidence from the Amathole District Municipality, Eastern Cape Province, South Africa. International Journal of Environmental Science and Development, 7, 687-692. https://doi.org/10.18178/ijesd.2016.7.9.863

[25] Mugiya, D. and Hofisi, C. (2017) Climate Change Adaptation Challenges Confronting Small-Scale Farmers. Environmental Economics, 8, 57-65. https://doi.org/10.21511/ee.08(1).2017.06

[26] Mulinya, C. (2017) Factors Affecting Small Scale Farmers Coping Strategies to Climate Change in Kakamega County in Kenya. Journal of Humanities and Social Sciences, 22, 100-109.

[27] Ampaire, E.L., Jassogne, L., Providence, H., Acosta, M., Twyman, J., Winowiecki, L. and Asten, P. (2017) Institutional Challenges to Climate Change Adaptation: A Case Study on Policy Action Gaps in Uganda. Environmental Science and Policy, 75, 81-90. https://doi.org/10.1016/j.envsci.2017.05.013

[28] Kabale District Local Government (KDLG) (2011) Kabale District Local Government Five Year Development Plan, 2011/201-2015/2016 (Vol. 1) Kabale.

[29] McCambell, I. (2015) Fertilizer Adoption Challenges among Potato Farmers in Uganda: Analysis of a Complex Problem Using an Innovation Systems. Wageningen Univeristy, Wageningen.

[30] GoU (2007) Uganda National Adaptation Programmes of Action. Kampala.

[31] Kanygume, S. (2015) Perception of Farmers to Climate Variability and Coping Strategies among Farming Communities in Bufundi Subcounty. Kenyatta University, Kenyatta. 
[32] Muhumuza, M., Muzinduki, P. and Hyeroba, G. (2010) Small Holder Farmers' Knowledge and Adaptation to Climate Change in the Rwenzori Region.

[33] Karanja, M. (2013) Analysis of Rainfall Variability on Irish Potato Production in Ol-Joro-Orok Division, Nyandarua County, Kenya. Kenyatta University, Kenyatta.

[34] Zizinga, A., Tenywa, M.M., Majaliwa, J.G.M., Mugarura, M. and Ababo, P. (2015) Potential Climate Change Adaptation and Coping Practices for Agricultural Productivity in the Mountain Areas of South Western Uganda. Journal of Scientific Research and Reports, 7, 23-41. https://doi.org/10.9734/JSRR/2015/16351

[35] Varga, Z. (2014) Facts about the Use of Agrometeorological Information in Hungary and Suggestions for Making That More Efficient. Quarterly Journal of the Hungarian Meteorological Service, 118, 79-92.

[36] CARE Poverty Environment and Climate Change Network (PECCN) (2011) Understanding Vulnerability to Climate Change: Insights from Applications of CARE'S Climate Vulnerability and Capability Analysis (CVCA) Methodology.

[37] Osbahr, H. (2007) Building Resilience: Adaptation Mechanisms and Mainstreaming for the Poor. Background Paper for UNDP Human Development Report 2007/2008, New York.

[38] Namwata, B. and Lwelamira, J.M.O.B. (2010) Adoption of Improved Agricultural Technologies for Irish Potatoes (Solanum tuberosum) among Farmers in Mbeya Rural District, Tanzania: A Case of Ilingu Ward. Journal of Animal \& Plant Sciences, 8, 927-935.

[39] Akongo, G.O., Buyinza, M. and Bua, A. (2016) Effects of Climate Variability on Technical Efficiency of Rice in Acholi and Lango Sub-Regions, Uganda. Journal of Economics and Sustainable Development, 7, 126-136.

[40] Tambo, J. (2016) Adaptation and Resilience to Climate Change and Variability in North East Ghana. International Journal of Disaster Risk Reduction, 17, 85-94. https://doi.org/10.1016/j.ijdrr.2016.04.005

[41] Oloo, G.I. (2013) Evaluation of Climate Change Adaptation Strategies and Their Effect on Food Production among Smallholder Farmers in Bungoma County, Kenya. Egerton University, Nakuru.

[42] Yong, D.N. (2014) Factors Affecting the Choice of Adaptation Measures to Climate Change: The Case of Famers in the Sudano-Sahelian Area of Cameroon. Tanzania Economic Review, 4, 56-72.

[43] Deressa, T.T., Hassan, R. and Ringler, C. (2010) Perception of and Adaptation to Climate Change by Farmers in the Nile Basin of Ethiopia. Journal of Agricultural Science, 149, 23-31. https://doi.org/10.1017/S0021859610000687

[44] Azhoni, A., Holman, I. and Jude, S. (2016) Contextual and Interdependent Cause of Climate Change Adaptation Barriers: Insights from Water Management Institutions in Himachal Pradesh. Science of Total Environmental Change, 576, 817-828. https://doi.org/10.1016/j.scitotenv.2016.10.151

[45] Kabale District Local Government (KDLG) (2015) Kabale District Five Year Development Plan, 2015/2016-2019/2020. Kabale. 